\title{
Efficacy of insecticides in fruit borer control and residues on sugar apple fruit
}

\author{
Alessandro da Silva Oliveira ${ }^{1}$, Maria Aparecida Castellani ${ }^{2}$, Aldenise Alves Moreira ${ }^{2}$, \\ Antônio Souza do Nascimento ${ }^{3}$, Mateus Silva Azevedo ${ }^{2}$, Vitoriano Gusmão Oliveira ${ }^{2}$
}

10.1590/0034-737X201764020004

\begin{abstract}
Bahia is the Brazilian state with the largest production of sugar apple fruits (Annona squamosa L.), and fruit borer (Cerconota anonella, Sepp. 1830) is a key crop pest. Insecticides are the main strategy for pest control even though there are no pesticides registered for this crop. This study aimed to assess the efficacy of insecticides to control fruit borer and determine the levels of insecticide residues in sugar apple fruits aiming at requesting the extension of authorization to use insecticide products in this crop. The experiment was conducted in an eight-year-old irrigated orchard $(2 \times 4 \mathrm{~m})$ located in Anagé, Bahia, Brazil. The experimental design was a randomized block design with 10 treatments (three insecticides with three doses and a control with water) and 5 replications. Each plot was composed of four plants but only the two central ones were assessed. Insecticides and doses (g a.i. $100 \mathrm{~L}^{-1}$ water) were Bacillus thuringiensis: $0.8,1.7$, and 2.5; triflumuron: 2.4,3.6, and 4.8; and imidacloprid: 4.0, 10.0, and 16.0. Nine sprayings were carried out at fortnightly intervals with a costal sprayer with constant pressure, JA-2 nozzle, and with jet directed to the fruits. Ten assessments were performed in order to observe fruit borer presence in 30 previously marked fruits per plot. Imidacloprid, at the highest studied dose, was the only effective treatment. Analyses of imidacloprid residues, at 21 and 30 days after the highest dose application, indicated levels higher than the maximum limit allowed. Insecticides under the conditions tested do not meet the norms for requesting the extension of authorization to use insecticides for citrus in sugar apple fruits.
\end{abstract}

Key words: Annona squamosa; biological control; chemical control; imidacloprid.

\section{RESUMO}

\section{Eficácia de inseticidas no controle da broca-do-fruto e avaliação de resíduos em frutos de pinha}

A Bahia é o maior produtor nacional de pinha (Annona squamosa L.) e a broca-do-fruto (Cerconota anonella, Sepp. 1830) é praga chave da cultura. O uso de inseticidas é a principal tática de controle da praga, mesmo não havendo registros de agrotóxicos para a cultura. Objetivou-se com este trabalho avaliar a eficácia de inseticidas para o controle da broca e determinar os níveis de resíduos dos inseticidas nos frutos, visando à solicitação de extensão de uso dos produtos para pinha. $\mathrm{O}$ experimento foi conduzido em pomar irrigado, adensado $(2 \times 4 \mathrm{~m})$ com oito anos, em Anagé, Bahia, Brasil. O delineamento foi em blocos casualizados com 10 tratamentos (três inseticidas em três doses e um tratamento testemunha - água) e cinco repetições. As parcelas compreenderam quatro plantas, sendo as duas centrais

Submitted on April 30 $0^{\text {th }}, 2014$ and accepted on February 14 $4^{\text {th }}, 2017$.

${ }^{1}$ Agência Estadual de Defesa Agropecuária da Bahia, Salvador, Bahia, Brazil. alessandro.oliveira1@adab.ba.gov.br

${ }^{2}$ Universidade Estadual do Sudoeste da Bahia, Departamento de Fitotecnia a Zootecnia, Vitória da Conquista, Bahia, Brazil. castellani@uesb.edu.br; aldenise.moreira@gmail.com; azevedo43@hotmail.com; totygusmão@hotmail.com

${ }^{3}$ Embrapa Mandioca e Fruticultura, Cruz das Almas, Bahia, Brazil. antonio-souza.nascimento@embrapa.br

*Corresponding author: castellani@uesb.edu.br 
úteis. Os inseticidas e as respectivas doses (g de i.a. $100 \mathrm{~L}^{-1}$ de água) foram: Bacillus thuringiensis: 0,8; 1,7; e 2,5; triflumurom: 2,4; 3,6; e 4,8; e imidacloprido: 4,0; 10; e 16. Foram realizadas nove pulverizações em intervalos quinzenais com pulverizador costal de pressão constante, bico JA-2, com jato dirigido aos frutos e 10 avaliações da presença da broca em 30 frutos por parcela marcados previamente. Eficácia de controle foi comprovada apenas para imidacloprido na maior dose estudada. Análises de resíduo do imidacloprido aos 21 e 30 dias após a aplicação da maior dose indicaram níveis superiores ao limite máximo permitido. Os produtos nas condições testadas não se enquadram nas normas para solicitação de extensão de uso de citros para pinha.

Palavras-chave: Annona squamosa; controle biológico; controle químico; imidacloprido.

\section{INTRODUCTION}

Annonaceae comprises a group of plants standing out worldwide for producing high commercial value fruits either for fresh or processed market, as well as for production of bioactive compounds. Regarding its economic importance, the three main Annonaceae species produce in Brazil are sugar apple (Annona squamosa L.), soursop (Annona muricata L.), and atemoya (Annona cherimola Mill. $\times$ Annona squamosa L.) (Lemos, 2014). Bahia state stands out as the main producer, being considered the largest national producer of sugar apple, with all-year-round production with high quality standards (GCEA/IBGE, 2016).

In the Neotropical region, fruit borer (Cerconota anonella, Sepp., 1830, Lepidoptera: Oecophoridae) is one of the most important pest species of Annona, requiring fruit growers to adopt mainly chemical control to suppress its population (Silva et al., 2006). In Brazil, this insect has become more important due to an increasing consumption of Annonaceae fruits, thus, occupying a primary pest status (Hamada et al., 1998; Braga Sobrinho et al., 1998, Bittencourt et al., 2007). Insect larvae are the main cause of production losses, at various stages of growth, initially damaging fruit peel and then pulp (São José, 2003). Fruit is mummified due to opportunistic fungus development and become twisted, making commercialization unfeasible (Oliveira et al., 2004). In addition to peel and pulp damages, seed injuries have already been reported (Braga Filho et $a l ., 2007)$. Females of $C$. anonella lay eggs on fruit surface and, under high infestation conditions, on flowers (Silva et al., 2006). Shortly after hatching, caterpillars take shelter within fruit natural cracks, protecting themselves with silk threads; they scrape fruit surface and, after 3 to 4 days, penetrate into them (Bittencourt et al., 2007).

Despite the importance of fruit borer, few studies have aimed at managing these insect populations. Among these studies, the ones worthy of mention are crop practice recommendations (São José, 1997; Braga Sobrinho et al., 1998; Bittencourt et al., 2007), fruit bagging (Broglio-
Micheletti et al., 2001), as well as studies on natural enemies (Broglio-Micheletti \& Berti-Filho, 2000; Oliveira et al., 2001) which aim to reduce pest populations. Unfortunately, insecticide spraying is the control method often used by fruit growers. Even with the recommendations of this control method (Araújo Filho et al., 1998; São José, 2003), associated or not with natural products (Pereira et al., 2009; Brito, 2010), there are no pesticides registered in the Brazilian Ministry of Agriculture, Livestock, and Food Supply (MAPA) for Annonaceae orchards.

Since several crops are in the same situation as Annonaceae, the Brazilian Ministry of Agriculture and Livestock (MAPA), together with the Brazilian Institute for the Environment and Renewable Natural Resources (IBAMA), and the Brazilian Health Regulatory Agency (ANVISA) published a Joint Normative Instruction (INC), No. 01 of February 23, 2010 (Brasil, 2010). It establishes the guidelines and requirements for authorization for agrochemicals and their components already registered in crops with insufficient phytosanitary support, as well as the maximum residue limit allowed.

For this reason and considering the increasing importance of sugar apple to Bahia state, this study aimed to assess the efficacy of insecticides to control fruit borer and determine the residue levels of efficient insecticides in sugar apple fruits aiming at requesting the extension of authorization to use insecticide products in this crop.

\section{MATERIAL AND METHODS \\ Efficacy of insecticides to control Cerconota anonella}

The studies were carried out at Canaã Farm, Anagé, Bahia, Brazil, in the village of Angico, on the banks of the Gavião River ( $14^{\circ} 262 \mathrm{~S}$ and $41^{\circ} 432 \mathrm{~W}$ ), with an altitude of $366 \mathrm{~m}$. According to Köppen, regional climate is very hot semiarid with summer rains (Bswh'). Local soil is a Dystrochrept with a good drainage condition (Silva et al., 2007). 
Evaluations were carried out in a commercial 8-year-old sugar apple orchard with 25 hectares $(2 \times 4 \mathrm{~m}$ spacing $)$. This orchard is representative of the regional fruit growers, with high technological level, including micro sprinkler irrigation and cultural and chemical controls of pests and diseases, and its total production is sold to São Paulo state, Brazil.

Insecticide selection (Table 1) was performed based on the guidelines and requirements of INC No.01/2010 (Brasil, 2010). Initially, a survey of the products that had been used to control $C$. anonella at the Anagé and Presidente Dutra fruit poles was carried out. The products in use (methamidophos and endosulfan) had already been set to be removed from the market by 2013 (Resolutions of the Collegiate Board of Directors, RDC No. 01 of January 14, 2011, and No. 28 of August 09, 2010).

Three insecticides with different modes of action were used. Triflumuron acts as a chitin synthesis inhibitor, Bacillus thuringiensis Berliner acts in the insect digestive tract, especially in caterpillars, and imidacloprid acts as a neurotoxin that interferes with the action of nicotinic acetylcholine receptors, with a systemic action. The insecticides have a concentrated suspension formulation, with registration in the Agricultural Protection Agency of Bahia (ADAB) and MAPA (Table 2).

The experimental design was a randomized block design with 10 treatments and five replications, with plots of $28 \mathrm{~m}^{2}$ that consisted of four plants, but only the two central were used for assessments, totaling an experimental area of $1,400 \mathrm{~m}^{2}$. Treatments consisted of the use of three insecticides in three doses (indicated dose for citrus and two smaller doses), in addition to a control treatment (water) (Table 2).

Nine sprayings were carried out at fortnightly intervals, from February 18 to June 18, 2011. The first spraying was performed at seven days after pollination using a costal sprayer with constant pressure (maintained by compressed $\mathrm{CO}_{2}$ ) at 50 psi and cone nozzles model JA-2, with a jet directed to the fruits. Spray solutions were prepared and conditioned in 2-L containers, which were coupled to the sprayer for application.

About 30 fruits with no symptoms of fruit borer attack were selected per plot. These fruits were marked and

Table 1: Active ingredient, commercial product, toxicological classification, license holder, mode of action, and group of products used in the experiment of control efficacy of fruit borer (Cerconota anonella) in sugar apple (Annona squamosa). Anagé, BA, Brazil, 2011

\begin{tabular}{|c|c|c|c|c|c|}
\hline $\begin{array}{c}\text { Active } \\
\text { Ingredient }\end{array}$ & $\begin{array}{c}\text { Commercial } \\
\text { Product }\end{array}$ & $\begin{array}{c}\text { Toxicological } \\
\text { Classification }\end{array}$ & License Holder & Mode of Action & Group \\
\hline $\begin{array}{c}\text { Bacillus } \\
\text { thuringiensis }\end{array}$ & Dipel $^{\circledR}$ & $\begin{array}{l}\text { IV - Practically } \\
\text { Non-Toxic }\end{array}$ & $\begin{array}{c}\text { Sumitomo Chemical } \\
\text { of Brasil }\end{array}$ & $\begin{array}{l}\text { Ingestion - } \\
\text { disintegrator of } \\
\text { the mesentery } \\
\text { epithelium }\end{array}$ & Biological Agent \\
\hline Triflumuron & Certero $^{\circledR}$ & $\begin{array}{l}\text { IV - Practically } \\
\text { Non-Toxic }\end{array}$ & Bayer S.A. & $\begin{array}{l}\text { Contact, ingestion - } \\
\text { chitin synthesis } \\
\text { inhibitor }\end{array}$ & Benzoylurea \\
\hline Imidacloprid & Provado 200 SC $^{\circledast}$ & III - Slightly Toxic & Bayer S.A. & $\begin{array}{l}\text { Systemic - } \\
\text { acetylcholine agonist }\end{array}$ & Neonicotinoid \\
\hline
\end{tabular}

Table 2: Treatments (insecticides and control) assessed for control efficacy of fruit borer (Cerconota anonella) in sugar apple (Annona squamosa), commercial products, and doses used. Anagé, BA, Brazil, 2011

\begin{tabular}{|c|c|c|c|c|}
\hline \multirow{2}{*}{ Treatment } & \multicolumn{2}{|c|}{ Product } & \multicolumn{2}{|c|}{ Dose (in $100 \mathrm{~L}$ water) } \\
\hline & A. I. & Commercial Name & C.P.(L 100L ${ }^{-1}$ water $)$ & A.I. \\
\hline $\mathrm{T} 1$ & Control (water) & - & $\longrightarrow$ & $\longrightarrow$ \\
\hline $\mathrm{T} 2$ & Triflumuron & Certero $^{\circledR} 480 \mathrm{~g} \mathrm{~L}^{-1}$ & 0.005 & $2.4 \mathrm{~g}$ \\
\hline $\mathrm{T} 3$ & Triflumuron & & 0.075 & $3.6 \mathrm{~g}$ \\
\hline $\mathrm{T} 4$ & Triflumuron & & 0.010 & $4.8 \mathrm{~g}$ \\
\hline T5 & Bacillus thuringiensis & Dipel $^{\circledast 3} 33.6 \mathrm{~g} \mathrm{~L}^{-1}$ & 0.025 & $25 \mathrm{~mL}$ \\
\hline T6 & Bacillus thuringiensis & & 0.050 & $50 \mathrm{~mL}$ \\
\hline $\mathrm{T} 7$ & Bacillus thuringiensis & & 0.075 & $75 \mathrm{~mL}$ \\
\hline $\mathrm{T} 8$ & Imidacloprid & Provado $^{\circledast} 200 \mathrm{SC} 200 \mathrm{~g} \mathrm{~L}^{-1}$ & 0.020 & $4 \mathrm{~g}$ \\
\hline T9 & Imidacloprid & & 0.050 & $10 \mathrm{~g}$ \\
\hline $\mathrm{T} 10$ & Imidacloprid & & 0.080 & $16 \mathrm{~g}$ \\
\hline
\end{tabular}

A.I. - active ingredient; C.P. - commercial product.

Rev. Ceres, Viçosa, v. 64, n.2, p. 132-137, mar/abr, 2017 
assessed on symptoms of fruit borer attack before each spraying, totaling nine assessments. Fruits that presented signs of the presence of fruit borer and droppings, dark peel color, and were mummified, with penetration holes, (Bittencourt et al., 2007) were considered as having symptoms. These fruits were counted for subsequent calculation of infested fruit percentage.

The percentage of infested fruit data was transformed into $\sqrt{\mathbf{x}+0,5}$ and submitted to analysis of variance. The significance in relation to the control treatment was verified by the Dunnett test. All analyses were performed by means of the Program Statistical Analysis System, SAS version 9.3. The Abbott's formula was used to calculate the product efficacy from the non-transformed data (Nakano et al., 1981).

\section{Analysis of insecticide residue}

Based on product efficacy, two residue analyses of the active ingredient imidacloprid were performed after spraying the product in a dose of $16 \mathrm{~g}$ a.i. $\mathrm{L}^{-1}$ water, using the same equipment and methodology described previously. At 21 and 30 days after spraying, $1.0 \mathrm{~kg}$ of fruits were randomly collected in the sprayed area and Styrofoam-packed with reusable artificial ice, taking care that the ice did not come in contact with the fruit in order to avoid damage to the peel. Subsequently, these samples were taken to the Institute of Technology of Pernambuco (ITEP), Pernambuco, Brazil, for analysis of liquid chromatography coupled to mass spectrometry technique using the equipment UPLC XEVO TQS-S (Waters Technologies do Brasil).

\section{RESULTS AND DISCUSSION}

\section{Efficacy of insecticides to control Cerconota anonella}

The average percentages of fruits infested with $C$. anonella are shown in Table 3. Significant differences between treatments and control were observed in the third, fourth, and fifth assessments. In the third assessment, the treatments $B$. thuringiensis at a dose of $25 \mathrm{~mL}$ a.i. and imidacloprid at the three studied doses allowed a significant infestation reduction. In the fourth and fifth assessments, only imidacloprid at doses of 10 and $16 \mathrm{~g}$ a.i., respectively, differed significantly from the control (Table 3).

Insecticides with contact or ingestion mode of action could act on newly hatched caterpillars since they shelter in natural cracks of fruits, scrape their surface to feed, and only 3 to 4 days after hatching penetrate the fruit (Bittencourt et al., 2007), leading to mortality before or shortly after fruit penetration. Regarding the $B$. thuringiensis-based insecticide, which acts on ingestion, a greater action was expected in reducing fruit borer symptoms because, theoretically, there would be sufficient time for caterpillar contamination when scraping fruit peel before penetration. Monteiro \& Souza (2010) demonstrated that $B$. thuringiensis var. kurstaki-based formulations are as efficient as tebufenozide- and chlorpyrifos-based chemical products for controlling Grapholita molesta (Busck) and Bonagota cranaodes (Meyrick) (Lepidoptera: Tortricidae) in the apple tree.

The triflumuron-based product did not allow a significant reduction of fruit borer damages, which was not expected since the product is also registered for controlling citrus fruit borer (Gymnandrosoma aurantianum Lima, 1927) in citrus (Agrofit, 2012). This product inhibits chitin synthesis, acting more slowly in the insect. Theoretically, caterpillar contamination would occur before its penetration into the fruits, with mortality inside them. In this study, first instar caterpillar contamination probably did not prevent the occurrence of infestation symptoms by fruit borer and the entry of opportunistic fungi. The opening of treated fruits in order to verify whether the caterpillars died would be of great value for improving the assessment methodology.

Imidacloprid provided a significant reduction in $C$. anonella damage from the second assessment, standing out the higher doses. This is a systemic product, i.e. when applied to leaves, branches, and roots of plants; it is rapidly absorbed and translocated with the sap flow to several plant parts, being in lethal amounts to insects (Faria, 2009).

Broglio-Micheletti et al. (2001) reported unsatisfactory efficiency results of triflumuron and imidacloprid encapsulated with plastic and paper coatings for controlling C. anonella and Bephratelloides pomorum (Fab.) (Hymenoptera: Eurytomidae) in soursop. According to the authors, the most effective and economical way to control these pests in soursop is the use of a common plastic bag or perforated plastic.

Considering the efficiency percentages of the studied products (Table 4), B. thuringiensis- and triflumuron-based insecticides were not effective at all doses and assessment periods. Imidacloprid showed an efficacy higher than $80 \%$ in the two highest doses, being efficient in the third and fourth assessments at a dose of $10 \mathrm{~g}$ a.i. whereas at the highest dose, the efficacy was demonstrated in the fourth $(83.6 \%)$ and from sixth to tenth assessments, reaching $100 \%$.

In this study, applications were started at 7 days after pollination, a period during which fruits were about $1.5 \mathrm{~cm}$ diameter, with no phytotoxicity or abortion symptoms. Chemical protection of fruits against $C$. anonella attack could be achieved for almost the entire fruiting period by using imidacloprid at the highest dose at fortnightly applications. Furthermore, the insecticide that presented the best performance in controlling $C$. anonella was that of systemic action. This fact, associated with the irregularity of maturation and harvest of sugar apple fruits of the same plant, raises concerns regarding the waiting period, in 
which is intended to avoid the occurrence of residues in the fruits in contents above those allowed.

\section{Analysis of imidacloprid residue}

Because the imidacloprid was efficient in six assessments, the residue analysis of this pesticide was performed in the fruit when applied at the highest dose at 21 and 30 days after application. The results indicated the presence of 0.02 and $0.017 \mathrm{mg} \mathrm{kg}^{-1}$ at 21 and 30 days, respectively. However, the Maximum Residue Limit allowed in the reference crop (citrus) is $0.01 \mathrm{mg} \mathrm{kg}^{-1}$. Therefore, both for the waiting period stipulated for citrus (21 days) and for a longer period (30 days), the product is inappropriate for using in sugar apple when sprayed directly on the fruit.

In the Brazilian Official Gazette (DOU) of July 19, 2012, a bulletin was published by IBAMA that formally initiates the process of reassessment of pesticides associated with harmful effects on bees and the prohibition of spraying during and immediately after flowering. Among the products listed is the imidacloprid.
Thus, although studies indicate that imidacloprid is selective to predators and parasitoids in some crops such as bean (Marquini et al., 2003), worldwide this compound has been associated with lethal effects on some insect species. In termites of the species Heterotermes tenuis (Hagen) (Isoptera: Termitidae), sublethal concentrations of imidacloprid altered the cleaning behavior of workers (Moino Jr. \& Alves, 1998) whereas in bees, sublethal doses of the insecticides imidacloprid, fipronil, and deltamethrin determine changes in learning and memory performance during the foraging process (Decourtye et al., 2003).

Therefore, it is important to consider that sugar apple harvesting management is staggered and hence there will always be areas of the orchard in flowering and others in fruiting, making it unfeasible to adequate cultivation areas to the prohibitions established by IBAMA for the use of neonicotinoids. Thus, until new studies on the extension of authorization to use pesticides in sugar apple be carried out, a phytosanitary education program is essential for fruit growers.

Table 3: Average percentage (\%) of sugar apple fruits (Annona squamosa) infested by fruit borer (Cerconota anonella) as a function of insecticide treatments and control and assessment period. Anagé, BA, Brazil, 2011

\begin{tabular}{lccccccccc}
\hline \multirow{2}{*}{ Treatment } & \multicolumn{7}{c}{ Assessment } \\
\cline { 2 - 10 } & 1st\% & 2nd\% & 3rd\% & 4th\% & 5th\% & 6th\% & 7th\% & 8th\% & 9th\% \\
\hline Triflumuron-2.4 g a.i. & 3.39 & 6.53 & 11.15 & 6.47 & 12.03 & 11.73 & 12.34 & 12.34 & 12.34 \\
Triflumuron-3.6 g a.i. & 2.51 & 8.42 & 6.72 & 6.70 & 7.89 & 7.89 & 6.94 & 6.94 & 7.89 \\
Triflumuron-4.8 g a.i. & 3.83 & 10.95 & 14.89 & 15.26 & 18.46 & 14.66 & 13.49 & 12.77 & 13.49 \\
Bacillus thuringiensis -25 mL a.i. & 3.15 & 6.48 & $5.59 * * *$ & 6.08 & 13.68 & 10.92 & 10.15 & 10.92 & 10.92 \\
Bacillus thuringiensis-50 mL a.i. & 4.42 & 6.75 & 11.35 & 13.54 & 18.50 & 11.38 & 9.11 & 11.82 & 10.64 \\
Bacillus thuringiensis-75 mL a.i. & 4.36 & 8.62 & 11.01 & 10.37 & 17.26 & 13.48 & 13.48 & 13.48 & 13.48 \\
Imidacloprid-4 g a.i. & 6.16 & 6.79 & $5.25^{* * *}$ & 6.08 & 14.18 & 8.84 & 8.16 & 8.16 & 8.14 \\
Imidacloprid-10 g a.i. & 1.71 & 2.37 & $2.27^{* * *}$ & $1.23 * * *$ & 8.06 & 3.58 & 3.84 & 4.58 & 3.84 \\
Imidacloprid-16 g a.i. & 5.36 & 4.44 & $2.27^{* * *}$ & 4.70 & $0.53 * * *$ & 0.00 & 0.00 & 0.51 & 0.71 \\
Control & 7.00 & 11.62 & 16.58 & 16.39 & 18.44 & 9.68 & 5.91 & 2.67 & 3.65 \\
\hline
\end{tabular}

*** - significant by the Dunnet test at $5 \%$.

Tabela 4: Insecticide efficacy (\%) in controlling fruit borer (Cerconota anonella) in sugar apple (Annona squamosa) as a function of assessment period. Anagé, BA, Brazil, 2011

\begin{tabular}{lrrrrrrrrr}
\hline \multirow{2}{*}{ Treatment } & \multicolumn{10}{c}{ Assessment } \\
\cline { 2 - 10 } & 2nd\% & 3rd\% & 4th\% & 5th\% & 6th\% & 7th\% & 8th\% & 9th\% & 10th\% \\
\hline Triflumuron - 2.4 g a.i. & 51.57 & 43.85 & 32.74 & 48.33 & 34.92 & 0.00 & 0.00 & 0.00 & 0.00 \\
Triflumuron - 3.6 g a.i. & 64.17 & 27.45 & 59.49 & 59.13 & 57.32 & 18.46 & 0.00 & 0.00 & 0.00 \\
Triflumuron-4.8 g a.i. & 45.29 & 5.78 & 10.16 & 0.00 & 25.88 & 0.00 & 0.00 & 0.00 & 0.00 \\
Bacillus thuringiensis - 25 mL & 7.00 & 44.25 & 66.27 & 62.91 & 0.00 & 0.00 & 0.00 & 0.00 & 0.00 \\
Bacillus thuringiensis - 50 mL a.i. & 36.91 & 41.91 & 31.55 & 17.39 & 6.62 & 0.00 & 0.00 & 0.00 & 0.00 \\
Bacillus thuringiensis - 75 mL a.i. & 37.70 & 25.82 & 33.60 & 36.71 & 23.30 & 0.00 & 0.00 & 0.00 & 0.00 \\
Imidacloprid -4 g a.i. & 11.89 & 41.59 & 68.34 & 62.90 & 23.30 & 15.73 & 0.00 & 0.00 & 0.00 \\
Imidacloprid - 10 g a.i. & 75.57 & 79.58 & 86.31 & 92.48 & 56.42 & 60.31 & 35.02 & 0.00 & 0.00 \\
Imidacloprid - 16 g a.i. & 23.41 & 61.83 & 83.58 & 71.33 & 97.15 & 100.00 & 100.00 & 80.77 & 80.44 \\
\hline
\end{tabular}

Rev. Ceres, Viçosa, v. 64, n.2, p. 132-137, mar/abr, 2017 


\section{CONCLUSIONS}

Among the studied products, imidacloprid presented control efficacy for Cerconota anonella.

At 21 days after imidacloprid application, the active ingredient residue present in the fruit was twice higher than allowed.

The products under the study conditions do not meet the requirements of INC No. 01 of January 23, 2010, not being recommended for extension of authorization to be used in sugar apple.

\section{REFERENCES}

Agrofit: Sistema de agrotóxicos fitossanitários (2012) Available at: http://extranet.agricultura.gov.br/agrofit_cons/principal_agrofit_cons. Accessed on: February 15th, 2012.

Araújo Filho GC, Andrade OMS, Castro FA \& Sá FT (1998) Instrução técnica para o cultivo da ateira. Fortaleza, Embrapa. 9p. (Instruções técnicas, 01).

Bittencourt MAL, Sobrinho CM \& Pereira MJB (2007) Biologia, danos e táticas de controle da broca-da-polpa das anonáceas. Revista Bahia Agrícola, 8:16-17.

Braga Sobrinho R, Cardoso JE \& Freire FCO (1998) Pragas de fruteiras tropicais de importância agroindustrial. Brasília, Embrapa-SPI/ Fortaleza, Embrapa-CNPAT. p.131-141.

Braga Filho JR, Veloso VRS, Naves RV, Nascimento JL \& Chaves LJ (2007) Danos causados por insetos em frutos e sementes de araticum (Annona crassiflora Mart.,1841) no cerrado de Goiás. Jornal de Biociência, 23:21-28.

Brasil - Ministério da Agricultura, Pecuária e Abastecimento (2010) Instrução Normativa Conjunta n. 01 de 23 de fevereiro de 2010. Available at: <http://www.ceasa.gov.br/dados/ publicacao/IN\%2001>.Accessed on: August 22 $2^{\text {th }}, 2012$.

Brito ADFS (2010) Estudo do mercado da pinha (Annona squamosa L.) produzida no Estado da Bahia, Brasil. Dissertação de Mestrado. Universidade Estadual do Sudoeste da Bahia, Vitória da Conquista. 95p.

Broglio-Micheletti SMF \& Berti-Filho E (2000) Controle de Cerconota anonella em pomar de gravioleira. Scientia Agrícola, 57:557-559.

Broglio-Micheletti SMF, Agra AGSM, Barbosa GVS \& Gomres FL (2001) Controle de Cerconota anonella (Sepp.) (Lep.; Oecophoridae) e de Bephatelloides pomorum (Fab.) (Hym.: Eurytomidae) em frutos de graviola (Annona muricata L.). Revista Brasileira de Fruticultura, 23:722-725.

Decourtye A, Lacassie E \& Pham-Delègue (2003) Learning performances of honeybees (Apis mellifera L.) are differentially affected by imidacloprid according to the season. Pest Management Science, 59:269-278.

Faria ABC (2009) Revisão sobre alguns grupos de inseticidas utilizado no manejo integrado de pragas florestais. Ambiência, $5: 345-348$.

GCEA/IBGE - Grupo de Coordenação de Estatísticas Agropecuárias / Instituto Brasileiro de Geografia e Estatistica (2016)Levantamento Sistemático da Produção Agrícola, 2016. Available at: <www.sidra.ibge.gov.br/bda/agric/default.asp?t=2\&z=t\&o= $11 \& u 1=\& u 3=1 * u 4=1 \& u 5=1 \& u 6=1 \& u 2=1>$. Accessed on: Aug 20,2016
Hamada N, Gomes ALS, Couturier G \& Ronchi-Teles B (1998) Insetos associados à gravioleira (Annona muricata L., ANNONACEAE) na região de Manaus, Amazonas, Brasil. Acta Amazonica, 28:425-231.

Lemos EEP (2014) A produção de anonáceas no Brasil. Revista Brasileira de Fruticultura. Jaboticabal, 36:77-85.

Marquini F, Picanço MC, Guedes RNC \& Ferreira PSF (2003) Imidacloprid impact on arthopods associated with canopy of common beans. Neotropical Entomology, Londrina, 32:335342 .

Moino Jr A \& Alves SB (1998) Efeito de imidacloprid e fipronil sobre Beauveria bassiana (Bals.) Vuill. e Metarhizium anisopliae (Metsch) Sorok. e no comportamento de limpeza de Heterotemes tenuis (Hagen). Anais da Sociedade de Entomologia do Brasil, 27:611-619.

Monteiro LB \& Souza A (2010) Controle de tortricídeos em macieira com duas formulações de Bacillus thuringiensis var. kustaki em Fraiburgo-SC. Revista Brasileira de Fruticultura, 32:423428.

Nakano O, Silveira Neto S \& Zucchi RA (1981) Entomologia econômica. Piracicaba, Livroceres. 314p.

Oliveira MAS, Junqueira NTV, Icuma IM, Alves RT, Oliveira JNS \& Andrade GA (2001) Incidência de danos da broca do fruto da graviola no Distrito Federal. Brasília, Embrapa. p.01-05 (Comunicado Técnico, 51).

Oliveira LPS, Souza GD \& Silva RA (2004) Cerconota anonella (Sepp., 1830) (Lepidoptera: Oecophoridae), a principal praga da gravioleira. Revista Científica Eletrônica de Agronomia, Ano III, Edição 5. n.p.

Pereira MCP, Bandeira N, Antunes Júnior RC, Neitsche S, Oliveira Júnior MX, Alvarenga CD, Santos TM \& Oliveira JR (2009) Efeito do ensacamento na qualidade dos frutos e na incidência da broca-dos-frutos da atemoieira e da pinheira. Revista de Ciências Agronômicas, 68:389-396.

Silva CE, Gonçalves GB, Freitas MRT \& Sant‘ana AEG (2006) Reproductive behaviour of the fruit borer, Cerconota anonella. Etholgy, 112:971-976.

Silva JCG, Chaves MA, São José AR, Rebouças TNH \& Alves JFTA (2007) Influência da cobertura morta sobre características físicas e químicas de frutos da pinha (Annona squamosa L.). Revista Brasileira de Fruticultura, 29:287-291.

São José AR (1997) Aspectos gerais das anonáceas no Brasil. In: São José AR, Souza IVB, Morais OM \& Rebouças TNH (Ed.)Anonáceas: produção e mercado (Pinha, Graviola e Cherimóia). Vitória da Conquista, Universidade Federal do Sudoeste da Bahia. p.5-6.

São José AR (2003) Cultivo e mercado da graviola. Fortaleza, Instituto Frutal. 24p. 